\title{
The Effect of Heat Modification and Densification on Physical
Properties of Poplar Wood
}

\section{Utjecaj toplinske modifikacije i ugušćivanja na fizikalna svojstva topolovine}

\author{
Original scientific paper • Izvorni znanstveni rad \\ Received - prispjelo: 24. 3. 2017. \\ Accepted - prihvaćeno: 1. 12. 2017. \\ UDK: $630 * 812.421 ; 630 * 812.46 ; 674.031 .623 .23$ \\ doi:10.5552/drind.2017.1719
}

\begin{abstract}
In this study, density, volumetric swelling, mass loss, volume weight, fiber saturation point and water absorption of the poplar wood (Populus usbekistanica) were investigated with the effect of heat modification (HM) and heat-modified densification (HMD). Poplar samples were modified with steam at $120^{\circ} \mathrm{C}, 160^{\circ} \mathrm{C}$ and $200{ }^{\circ} \mathrm{C}$ for 1 and $3 \mathrm{~h}$. After heat modification, the samples were compressed in hot press at a temperature of $120^{\circ} \mathrm{C}$, press pressure of $5 \mathrm{MPa}$ and press time of 30 minutes for densification. Physical properties of the samples were determined according to Turkish standards. The results showed that heat modification affected densification and increased density. Densification had a positive effect on oven dry density $\left(D_{0}\right)$, oven dry density after soaking $\left(D_{0 s}\right)$, volume weight $(R)$ and fiber saturation point (FSP), except for volumetric swelling. Similarly, the densification process had an increasing effect on the water absorption, excluding 360 hours.
\end{abstract}

Keywords: poplar wood, densification, heat modification, physical properties

SAŽETAK • U ovoj je studiji istražen utjecaj toplinske modifikacije (HM) i ugušćivanja (HMD) na gustoću, volumno bubrenje, gubitak mase, volumnu težinu, točku zasićenosti vlakanaca i upijanje vode drva topole (Populus usbekistanica). Uzorci topolovine modificirani su parom pri 120,160 i $200{ }^{\circ} \mathrm{C}$ tijekom jednoga i tri sata. Nakon toplinske modifikacije uzorci su radi ugušćivanja stlačeni u vrućoj preši, pri temperaturi $120{ }^{\circ} \mathrm{C}$, tlaku prešanja 5 MPa i vremenu prešanja 30 minuta. Fizikalna svojstva uzoraka utvrđena su prema Turskim standardima. Rezultati su pokazali da je toplinska modifikacija utjecala na proces ugušćivanja i pridonijela povećanju gustoće. Ugušcivanje je imalo pozitivan učinak na gustoću topolovine u apsolutno suhom stanju $\left(D_{0}\right)$, na njezinu gustoću u apsolutno suhom stanju nakon natapanja $\left(D_{0 s}\right)$, na volumnu težinu $(R)$ i na točku zasićenosti vlakanaca (FSP), ali ne i na volumno bubrenje. Također, ugušćivanje je znatnije utjecalo na sposobnost upijanja veće količine vode, osim za vrijeme od 360 sati.

Ključne riječi: topolovina, ugušćivanje, toplinska modifikacija, fizikalna svojstva

\footnotetext{
${ }^{1}$ Authors are Ph.D. and professor at Department of Forest Industry Engineering, Faculty of Forestry, Kahramanmaras Sutcu Imam University, Kahramanmaras, Turkey.

${ }^{1}$ Autori su doktor znanosti i professor Odjela za inženjerstvo proizvoda od drva, Šumarski fakultet, Sveučilište Kahramanmaras Sutcu Imam, Kahramanmaras, Turska.
} 


\section{INTRODUCTION}

\section{UVOD}

There have been many studies on heat modification recently, due to its many advantages such as improving the dimensional stability and durability of wood, without using chemicals (Tjeerdsma et al.; 1998; Weiland et al.; 2003; Garcia et al., 2012). This technology was applied to wood at a temperature of about $200^{\circ} \mathrm{C}$ for several hours at low oxygen level, a non-inflammable gas like oil or nitrogen. The main aim of this technique is to convert the chemical composition of wood using heat, which results in a change of physical properties. The process of thermal modification is based on high temperatures, which cause the decomposition of basic wood component like hemicelluloses and celluloses (Tjeerdsma and Militz, 2005; Rowell et al., 2009). Schneider (1973) noted that treatment, at temperatures above $200{ }^{\circ} \mathrm{C}$ and of longer duration, decreased swelling and shrinkage up to $50 \%$. Besides, he stated that sorption and desorption characteristics also changed in heat modified wood.

In 1980s, densified wood products were produced from low density wood species, especially for utilization of some fast growing trees (Wang et al., 2000). The utilization of hardwood species for flooring and furniture reduced their supply all over the world. Various efforts have been made to modify the surface of low-quality softwood and planted fast-growing species. The surface densification technology has been developed and several researches have studied this technology (Rautkari et al., 2008; Gong and Lamason, 2007; Diouf et al., 2011). The thermal compression process might affect the drying duration, dimensional stability, surface quality, hygroscopicity, durability, and mechanical properties (Welzbacher et al., 2008).

The aim of this research is to determine the interactive effect of heat modification and post-heat densification on the poplar wood. The specific objective of the study was to analyze volumetric swelling and other chosen properties of heat threated and densified samples compared with samples densified without heat modification. These properties are: density, mass loss, volume weight, fiber saturation point and water uptake.

\section{MATERIALS AND METHODS}

\section{MATERIJALI I METODE}

Populus trees were obtained from Kahramanmaraş province in Turkey. Wood samples used in the study were prepared in dimensions $20 \times 20 \times 30 \mathrm{~mm}$. For each group of modification, 27 samples were prepared from logs. Before testing, each sample was conditioned at 20 ${ }^{\circ} \mathrm{C}$ temperature and at $65 \%$ relative humidity until reaching a moisture content of $12 \%$.

The samples were first heat modified by using laboratory drying oven at a temperature of $120^{\circ} \mathrm{C}, 160$ ${ }^{\circ} \mathrm{C}$ and $200{ }^{\circ} \mathrm{C}$ and modification time of either 60 or $180 \mathrm{~min}$ (Table 1). During heat modification, $100 \mathrm{ml}$ water vapor was heated up to $100{ }^{\circ} \mathrm{C}$ degrees in the oven, and then the vapor was removed and kept still until the desired temperatures reached $120^{\circ} \mathrm{C}, 160{ }^{\circ} \mathrm{C}$ and $200^{\circ} \mathrm{C}$. After the heat modification, samples were hot pressed by using a laboratory hot press at $120^{\circ} \mathrm{C}$ temperature and $5 \mathrm{MPa}$ press pressure for 30 minutes (Table 1).

The obtained results were statistically analyzed by using one-way ANOVA and Duncan's mean separa-

Table 1 Parameters used in tests of samples - undensified and densified

Tablica 1. Parametri obrade toplinski modificiranih uzoraka, neugušćenih i ugušćenih

\begin{tabular}{|c|c|c|c|c|c|}
\hline $\begin{array}{c}\text { Treatment } \\
\text { Obrada }\end{array}$ & $\begin{array}{c}\text { Heat temperature } \\
\text { Temperatura } \\
\text { zagrijavanja } \\
{ }^{\circ} \mathrm{C} \\
\end{array}$ & $\begin{array}{c}\text { Heat time } \\
\text { Vrijeme } \\
\text { zagrijavanja } \\
\text { min }\end{array}$ & $\begin{array}{c}\text { Pressure } \\
\text { Tlak } \\
\mathrm{MPa}\end{array}$ & $\begin{array}{c}\text { Pressure temperature } \\
\text { Temperatura prešanja } \\
{ }^{\circ} \mathrm{C}\end{array}$ & $\begin{array}{c}\text { Pressure time } \\
\text { Vrijeme } \\
\text { prešanja } \\
\text { min } \\
\end{array}$ \\
\hline \multicolumn{6}{|c|}{ Undensified / Neugušćeni uzorci } \\
\hline Control / kontrolni uzorak & - & - & - & - & - \\
\hline \multicolumn{6}{|l|}{$\begin{array}{l}\text { Heat modified (HM) } \\
\text { Toplinski modificirani uzorci }\end{array}$} \\
\hline HM11 & 120 & 60 & - & - & - \\
\hline HM13 & 120 & 180 & - & - & - \\
\hline HM21 & 160 & 60 & - & - & - \\
\hline HM23 & 160 & 180 & - & - & - \\
\hline HM31 & 200 & 60 & - & - & - \\
\hline HM33 & 200 & 180 & - & - & - \\
\hline \multicolumn{6}{|l|}{ Densified / Ugušćeni uzorci } \\
\hline Control / kontrolni uzorak & - & - & 5 & 120 & 30 \\
\hline \multicolumn{6}{|l|}{$\begin{array}{l}\text { Heat modified (HM) } \\
\text { Toplinski modificirani uzorci }\end{array}$} \\
\hline HM11 & 120 & 60 & 5 & 120 & 30 \\
\hline HM13 & 120 & 180 & 5 & 120 & 30 \\
\hline HM21 & 160 & 60 & 5 & 120 & 30 \\
\hline HM23 & 160 & 180 & 5 & 120 & 30 \\
\hline HM31 & 200 & 60 & 5 & 120 & 30 \\
\hline HM33 & 200 & 180 & 5 & 120 & 30 \\
\hline
\end{tabular}


tion test to populate homogeneity groups that showed significant differences at the $95 \%$ confidence level.

Oven dry density $\left(D_{0}\right)$ : This term expresses the amount of substance in the full dry unit volume and it is calculated according to TS 2472.

Volume weight value $(R)$ : This value describes the amount of substance in the full wet unit volume and it is determined according to TS 2472.

Fiber saturation point (FSP) was calculated according to Turkish standards TS 2371 and Equation 1 given below:

$$
F S P=\frac{V_{\mathrm{S}}}{D_{0}} \cdot 100
$$

where $V_{\mathrm{s}}$ is volumetric swelling (\%).

Oven dry density after soaking $\left(D_{0 \mathrm{~S}}\right)$ : After soaking for 15 days in water, samples were dried to $0 \%$ moisture content and oven dry densities were determined according to TS 2472. Mass loss (ML), volumetric swelling $(\%)$ and water absorption $\left(W_{\mathrm{A}}\right)$ were calculated by equations (2), (3) and (4), respectively,

$$
M L=\left(\frac{M_{0}-M}{M_{0}}\right) \cdot 100
$$

$M L$ - mass loss (\%), $M_{\mathrm{o}}$ - mass of oven-dry sample before heat modification (gr), $M$ - mass of the sample after heat modification (gr).

$$
V_{\mathrm{s}}(\%)=\left(\frac{L-L_{0}}{L_{0}}\right) \cdot 100
$$

$V_{\mathrm{s}}$ - volumetric swelling (radial, tangential and longitudinal), $L$ - wet dimension after immersion in water (mm), $\mathrm{L}_{\mathrm{o}}$ - oven-dry dimension (mm),

$$
W_{\mathrm{A}}(\%)=\left(\frac{W-W_{0}}{W_{0}}\right) \cdot 100
$$

$W_{\text {A }}$ - water absorption, $W$ - weight after immersion in water (gr), $W_{\mathrm{o}}$ - oven-dry weight before immersion in water (gr).

\section{RESULTS AND DISCUSSION}

\section{REZULTATI I RASPRAVA}

Average oven density values of densified and undensified poplar wood samples with and without heat modification are shown in Table 2.
The effect of heat modification on density is given in Table 2. According to this Table, it can be seen that oven dry density of densified samples differs from that of undensified samples. Heat modification has not shown significant effect on undensified poplar and has caused $1 \%$ decrease in density. The highest decrease in density among undensified poplar was observed at $200{ }^{\circ} \mathrm{C}$ heat modification (HT31 and HT33). Means of samples densified with heat modification $\left(897 \mathrm{~kg} / \mathrm{m}^{3}\right)$ were compared to density of densified control samples $\left(668 \mathrm{~kg} / \mathrm{m}^{3}\right)$, and the results clearly showed that heat modification increased density by $34 \%$. The density of samples densified with and without heat modification was increased by 102 $\%$ and $174 \%$ on average, respectively. Gong et al. (2010) studied the effect of heat treatment on density between undensified and densified poplar (Populus tremuloides) and concluded that wood density in densified poplar decreased to $11 \%$ during the heat treatment, while density decreased to $2 \%$ in undensified poplar wood. In another words, they concluded that the heat treatment of densified poplar increased density. Wang and Cooper (2005) found that the density of densified wood was affected by compress temperature, press duration time, press closing time and humidity of samples before compressing

The average volumetric swelling is given in Figure 1 for undensified and densified poplar samples with and without heat modification. The undensified volumetric swelling values at 120 and $160{ }^{\circ} \mathrm{C}$ are higher than those of control samples but at $200{ }^{\circ} \mathrm{C}$ they are lower. These differences are insignificant $(p<0.062)$. Besides, the duration of heat modification did not indicate significant differences in all parameters, except for control samples. On the other hand, in densified samples, all temperatures and durations had a significant effect $(p<0.001)$ on respective values. Moreover, as the duration of heat modification rose, volumetric swelling decreased. The mean volumetric swelling of undensified and modified samples (10.1\%) decreased by $3.7 \%$ in comparison with the undensified control group (10.49\%). The value of modified and densified samples (180.35 \%) increased by $85.68 \%$ compared to their control samples (97.13\%).

Table 2 Average oven density $\left(\mathrm{kg} / \mathrm{m}^{3}\right)$ values of undensified and densified poplar wood; control and heat modified Tablica 2. Srednja vrijednost gustoće neugušćenih i ugušćenih uzoraka topolovine u apsolutno suhom stanju; vrijednosti kontrolnih i toplinski modificiranih uzoraka

\begin{tabular}{|l|c|c|c|}
\hline \multicolumn{1}{|c|}{$\begin{array}{c}\text { Treatment } \\
\text { Obrada }\end{array}$} & Densified / Ugušćeni & Undensified / Neugušćeni & $\begin{array}{c}\text { Increase / Povećanje } \\
\mathbf{\%}\end{array}$ \\
\hline Control / kontrolni uzorak & 668 & 331 & 102 \\
\hline Heat modified / Toplinski modificirani uzorci & & & 184 \\
\hline HM11 & 950 & 334 & 156 \\
\hline HM13 & 859 & 335 & 185 \\
\hline HM21 & 944 & 331 & 168 \\
\hline HM23 & 884 & 330 & 183 \\
\hline HM31 & 878 & 310 & 171 \\
\hline HM33 & 869 & 321 & 174 \\
\hline Average / prosječna vrijednost & 897 & 327 & \\
\hline
\end{tabular}

HM: Heat modified / toplinski modificirani uzorci 


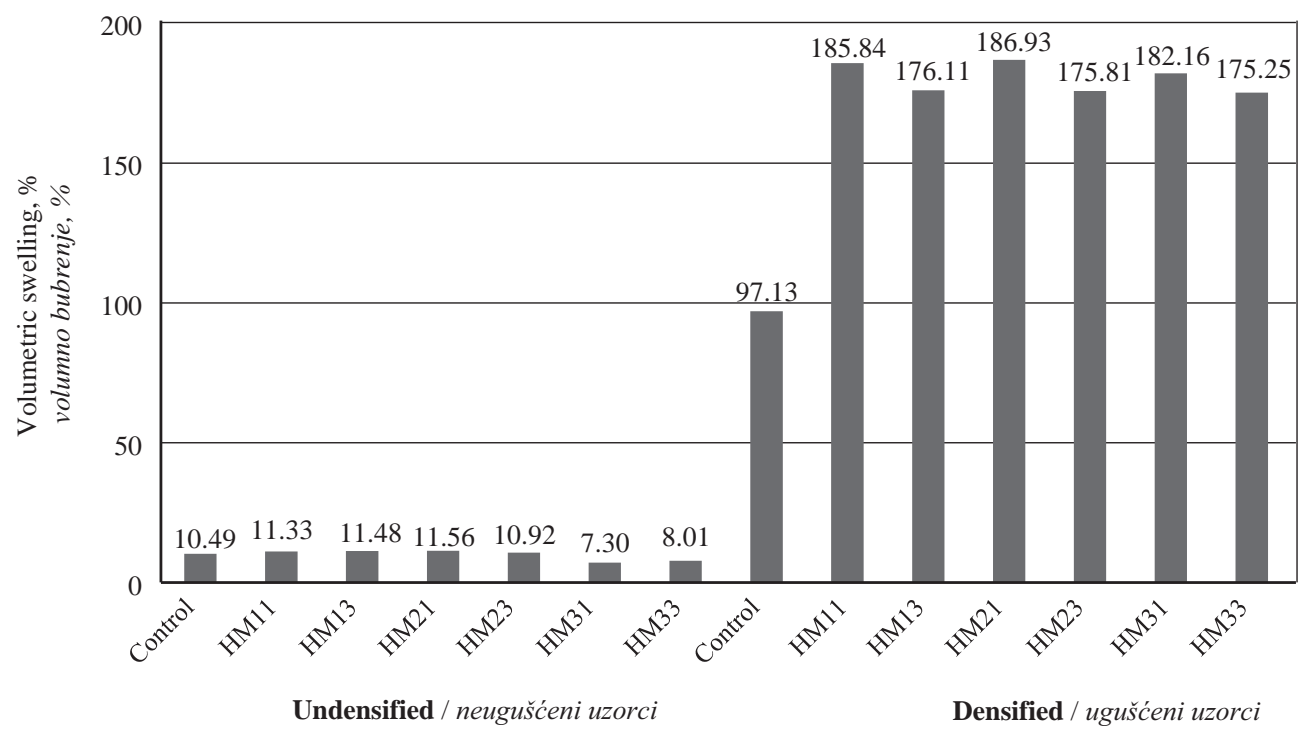

Figure 1 Average volumetric swelling of undensified and densified poplar wood with and without heat-modification Slika 1. Prosječno volumno bubrenje neugušćenih i ugušćenih te nemodificiranih i toplinski modificiranih uzoraka topolovine

Comparable results were recorded in other studies. For instance, Gong et al. (2010) studied the effect of heat modification on densification and stated that heat modified wood is more resistant to swelling than densified wood. Also, Bal and Bektaş (2012) noted that heat treatment without steam decreased thickness swelling specially above $180^{\circ} \mathrm{C}$. In some studies, it was noted that the relationship between volumetric swelling and oven dried density was potently positive (Table 3) (Kord et al., 2010; Kurt, 2010). Candan et al. (2013) noted that all thermally compressed boards increased thickness swelling values. This result could be explained by springback behavior of wood due to densification (Abraham et al., 2010).
The results of physical properties of undensified and densified poplar samples without and with heat modification are given in Table 3 .

Densification process with and without heat modification increased density values according to Table 3. The highest density for undensified poplar was observed for heat modification temperature of $120^{\circ} \mathrm{C}$ compared to control group. Table 3 shows that the densities measured at $20{ }^{\circ} \mathrm{C}$ in undensified samples seem to be lower, but this decrease is not significant. As seen from statistical results in Table 3, while heat temperature duration had no effect on density in undensified samples, a significant increase in density was observed when the duration of heat modification decreased from

Table 3 Comparison of physical properties of undensified and densified poplar wood

Tablica 3. Usporedba fizikalnih svojstava neugušćenih i ugušćenih uzoraka topolovine

\begin{tabular}{|l|c|c|c|c|c|}
\hline Treatment / Obrada & $\mathbf{D}_{\mathbf{0}}, \mathbf{g} / \mathbf{c m}^{\mathbf{3}}$ & $\mathbf{D}_{\mathbf{o s}}, \mathbf{g} / \mathbf{c m}^{\mathbf{3}}$ & $\mathbf{M L} \mathbf{\%}$ & $\boldsymbol{R}, \mathbf{g} / \mathbf{c m}^{\mathbf{3}}$ & $\boldsymbol{F S P} \mathbf{\%}$ \\
\hline Undensified / Neugušćeni uzorci & & & & & \\
\hline Control / kontrolni uzorak & $0.331 \mathrm{a}^{(*)}$ & $0.328 \mathrm{ab}$ & - & $0.299 \mathrm{a}$ & $31.74 \mathrm{a}$ \\
\hline Heat modified / Toplinski modificirani uzorci & & & & & \\
\hline HM11 & $0.334 \mathrm{a}$ & 0.333 & $0.30 \mathrm{a}$ & $0.299 \mathrm{a}$ & $33.92 \mathrm{a}$ \\
\hline HM13 & $0.335 \mathrm{a}$ & $0.324 \mathrm{~b}$ & $0.44 \mathrm{a}$ & $0.299 \mathrm{a}$ & $34.33 \mathrm{a}$ \\
\hline HM21 & $0.331 \mathrm{a}$ & $0.329 \mathrm{ab}$ & $1.05 \mathrm{ab}$ & $0.296 \mathrm{a}$ & $34.89 \mathrm{a}$ \\
\hline HM23 & $0.330 \mathrm{a}$ & $0.328 \mathrm{ab}$ & $1.82 \mathrm{bc}$ & $0.297 \mathrm{a}$ & $33.11 \mathrm{a}$ \\
\hline HM31 & $0.310 \mathrm{a}$ & $0.303 \mathrm{a}$ & $8.40 \mathrm{e}$ & $0.289 \mathrm{a}$ & $23.41 \mathrm{a}$ \\
\hline Dens3 & $0.321 \mathrm{a}$ & $0.316 \mathrm{ab}$ & $6.61 \mathrm{~d}$ & $0.296 \mathrm{a}$ & $24.99 \mathrm{a}$ \\
\hline Controd / kontrolni uzorak & & & & & \\
\hline Heat modified / Toplinski modificirani uzorci & & & & & \\
\hline HM11 & $0.668 \mathrm{~b}$ & $0.376 \mathrm{~cd}$ & & & \\
\hline HM13 & $0.950 \mathrm{~d}$ & $0.425 \mathrm{e}$ & $0.42 \mathrm{a}$ & $0.335 \mathrm{~b}$ & $195.58 \mathrm{c}$ \\
\hline HM21 & $0.859 \mathrm{c}$ & $0.394 \mathrm{~d}$ & $0.66 \mathrm{ab}$ & $0.323 \mathrm{~b}$ & $205.06 \mathrm{c}$ \\
\hline HM23 & $0.944 \mathrm{~d}$ & $0.386 \mathrm{~cd}$ & $0.97 \mathrm{ab}$ & $0.337 \mathrm{~b}$ & $197.98 \mathrm{c}$ \\
\hline HM31 & $0.884 \mathrm{c}$ & $0.366 \mathrm{c}$ & $1.49 \mathrm{abc}$ & $0.301 \mathrm{a}$ & $223.36 \mathrm{~d}$ \\
\hline HM33 & $0.878 \mathrm{c}$ & $0.396 \mathrm{~d}$ & $6.36 \mathrm{~d}$ & $0.322 \mathrm{~b}$ & $205.99 \mathrm{c}$ \\
\hline ANOVA & $0.869 \mathrm{c}$ & $0.393 \mathrm{~cd}$ & $2.60 \mathrm{c}$ & $0.327 \mathrm{~b}$ & $202.56 \mathrm{c}$ \\
\hline
\end{tabular}

$D_{0}$ - Oven dry density / gustoća u apsolutno suhom stanju; $D_{\mathrm{OS}}$ - Oven dry density after soaking / gustoća u apsolutno suhom stanju nakon natapanja; ML - Mass loss / gubitak mase; $R$ - Volume weight / volumna težina; FSP - Fiber saturation point / točka zasićenosti vlakanaca. "Means with the same small letter are not significantly different in Duncan's mean separation test. / Srednje vrijednosti označene istim malim slovom nisu signifikantno različite prema Duncanovu testu. 
3 to $1 \mathrm{~h}$ for densified poplar wood. As for densified samples, density decreased depending on the increase of the process duration (from 1 to $3 \mathrm{~h}$ ), except for the temperature of $200{ }^{\circ} \mathrm{C}$. No significant difference was observed. This is in accordance with literature data. For example, Metsä-Kortelainen and Viitanen (2011) determined that $120{ }^{\circ} \mathrm{C}$ heat modification increased density compared to control samples, while $200{ }^{\circ} \mathrm{C}$ heat modification decreased density due to degradation of hemicellulose and cellulose. In another study, Cao and Huang (2012) noted that steam-heat-modification increased wood thermal conductivity and density.

Comparing the mean oven dry density after soaking $\left(D_{0 \mathrm{~S}}\right)$ with oven dry density $\left(D_{0}\right)$, the density decreased $1 \%$ in undensified samples and decreased 55 $\%$ in densified samples as seen in Table 3 . This reduction occurred due to the permanent springback effect of the compressed wood. Densified and undensified poplar oven-dry densities after soaking $\left(D_{\text {os }}\right)$ decreased compared to $D_{0}$. However, $D_{0 \mathrm{~S}}$ of densified poplar wood was still higher after soaking compared to undensified samples.

Values given in Table 3 demonstrate that densification process did not cause mass loss but heat modification increased mass loss with increased temperature. ML values of poplar at $200{ }^{\circ} \mathrm{C}$ were greater than at 120 and $160{ }^{\circ} \mathrm{C}$. The average mass loss at 200, 160 and 120 ${ }^{\circ} \mathrm{C}$ was $6 \%, 1.33 \%$ and $0.45 \%$, respectively for all samples. A notably increased dimensional stability following thermal modification above $180{ }^{\circ} \mathrm{C}$ was noted in many studies (Welzbacher et al., 2008). This could be explained by the decreased hygroscopicity of components on wood cell walls (Fang et al., 2012). Decomposition of hemicelluloses and lignin at elevated temperatures and stress relaxation in samples caused a reduction in the hygroscopicity of wood (Cai et al., 2013). The value of volume weight of densified poplar
$(R)$ increased because density of densified poplar was higher than that of undensified poplar. The volume weight of densified wood increased by $9.31 \%$. The value of volume weight of undensified poplar $(R)$ decreased at $200{ }^{\circ} \mathrm{C}$ with heat modification compared to other temperatures. Furthermore, FSP is directly related to volumetric swelling and oven dry density according to Equation (1) mentioned in the Method section. As is known, there is a linear relationship between VS and FSP. The FSP value of the control group (undensified and control) was $31.74 \%$. After the samples were heat modified at $200{ }^{\circ} \mathrm{C}$ (the mean of HT31 and HT33), the FSP values decreased to $23.75 \%$ in poplar wood. Furthermore, the FSP values at $120^{\circ} \mathrm{C}$ and $160{ }^{\circ} \mathrm{C}$ increased by $7.3 \%$. The FSP value of the control group (densified and control) was $146.02 \%$. After the densification, the FSP values increased to $40.47 \%$. Bal and Bektas (2012) noted that heat treatment at higher temperatures $\left(180^{\circ} \mathrm{C}\right)$ decreased values of FSP. Additionally, the volumetric swelling is very high due to the back-spring effect of wood. Abraham et al. (2010) also noted that the densified wood exhibited this behavior. For this reason, the high springback effect has caused the FPS value to increase up to $223 \%$.

Table 4 shows that the effect of heat modification on water absorption (\%) differed between undensified and densified samples. It can be seen from Table 4 that, in the densified samples, the heat modification time had no statistically significant effect on water absorption at $120{ }^{\circ} \mathrm{C}$ (HM11, HM13), whereas at $200{ }^{\circ} \mathrm{C}$ (HM31, HM33) the respective effect was significant $(p<0.000)$. As shown in Table 4, the modification temperature and duration have no statistically significant effect in the first 48 hours only in heat modified (not densified) wood. The water absorption values of heat modified samples decreased after 48 hours compared to control group. However, in $72 \mathrm{~h}$ and $96 \mathrm{~h}$ there was no statistically sig-

Table 4 Water absorption (\%) of undensified and densified poplar wood without and with heat-modification

Tablica 4. Upijanje vode (\%) ugušćenih i neugušćenih te nemodificiranih i toplinski modificiranih uzoraka topolovine

\begin{tabular}{|l|c|c|c|c|c|c|c|c|}
\hline $\begin{array}{l}\text { Treatment } \\
\text { Obrada }\end{array}$ & $1 \mathrm{~h}$ & $2 \mathrm{~h}$ & $3 \mathrm{~h}$ & $24 \mathrm{~h}$ & $48 \mathrm{~h}$ & $72 \mathrm{~h}$ & $96 \mathrm{~h}$ & $360 \mathrm{~h}$ \\
\hline $\begin{array}{l}\text { Undensified } \\
\text { Neugušceni uzorci }\end{array}$ & & & & & & & & \\
\hline Control / kontrolni uzorci & $\left.7.64 \mathrm{a}^{*}\right)$ & $13.77 \mathrm{a}$ & $21.24 \mathrm{a}$ & $51.49 \mathrm{a}$ & $81.94 \mathrm{bcd}$ & $92.05 \mathrm{~b}$ & $99.19 \mathrm{~b}$ & $129.62 \mathrm{bcd}$ \\
\hline HM11 & $8.16 \mathrm{a}$ & $13.48 \mathrm{a}$ & $21.74 \mathrm{a}$ & $48.26 \mathrm{a}$ & $77.78 \mathrm{bc}$ & $88.92 \mathrm{~b}$ & $95.13 \mathrm{~b}$ & $129.19 \mathrm{bc}$ \\
\hline HM13 & $8.95 \mathrm{a}$ & $15.75 \mathrm{a}$ & $21.16 \mathrm{a}$ & $51.67 \mathrm{a}$ & $80.55 \mathrm{bcd}$ & $91.00 \mathrm{~b}$ & $99.83 \mathrm{~b}$ & $130.42 \mathrm{bcde}$ \\
\hline HM21 & $8.95 \mathrm{a}$ & $15.04 \mathrm{a}$ & $21.02 \mathrm{a}$ & $49.43 \mathrm{a}$ & $79.05 \mathrm{bcd}$ & $90.78 \mathrm{~b}$ & $99.53 \mathrm{~b}$ & $131.44 \mathrm{bcde}$ \\
\hline HM23 & $8.61 \mathrm{a}$ & $14.42 \mathrm{a}$ & $18.79 \mathrm{a}$ & $45.03 \mathrm{a}$ & $74.90 \mathrm{bc}$ & $87.81 \mathrm{~b}$ & $94.32 \mathrm{~b}$ & $122.71 \mathrm{bc}$ \\
\hline HM31 & $10.00 \mathrm{a}$ & $17.57 \mathrm{a}$ & $21.70 \mathrm{a}$ & $50.57 \mathrm{a}$ & $77.74 \mathrm{bc}$ & $100.74 \mathrm{~b}$ & $112.24 \mathrm{~b}$ & $150.44 \mathrm{def}$ \\
\hline HM33 & $6.25 \mathrm{a}$ & $11.50 \mathrm{a}$ & $17.39 \mathrm{a}$ & $43.28 \mathrm{a}$ & $68.51 \mathrm{ab}$ & $87.52 \mathrm{~b}$ & $95.32 \mathrm{~b}$ & $131.78 \mathrm{bcde}$ \\
\hline Densified / Ugušćeni uzorci & & & & & & & & \\
\hline Control / kontrolni uzorci & $30.98 \mathrm{~cd}$ & $54.44 \mathrm{~b}$ & $56.96 \mathrm{~b}$ & $84.12 \mathrm{~b}$ & $96.54 \mathrm{~d}$ & $105.50 \mathrm{~b}$ & $108.78 \mathrm{~b}$ & $119.02 \mathrm{~b}$ \\
\hline HM11 & $31.21 \mathrm{~cd}$ & $49.44 \mathrm{~b}$ & $58.55 \mathrm{~b}$ & $112.48 \mathrm{~cd}$ & $126.23 \mathrm{ef}$ & $132.82 \mathrm{c}$ & $135.64 \mathrm{~cd}$ & $151.00 \mathrm{ef}$ \\
\hline HM13 & $23.32 \mathrm{bc}$ & $50.15 \mathrm{~b}$ & $62.84 \mathrm{~b}$ & $107.05 \mathrm{c}$ & $122.02 \mathrm{e}$ & $127.69 \mathrm{c}$ & $130.33 \mathrm{c}$ & $149.29 \mathrm{cdef}$ \\
\hline HM21 & $36.20 \mathrm{cde}$ & $59.74 \mathrm{~b}$ & $80.25 \mathrm{c}$ & $126.09 \mathrm{~d}$ & $141.08 \mathrm{f}$ & $156.15 \mathrm{~d}$ & $150.80 \mathrm{~d}$ & $167.31 \mathrm{f}$ \\
\hline HM23 & $48.24 \mathrm{e}$ & $62.70 \mathrm{~b}$ & $69.70 \mathrm{bc}$ & $78.80 \mathrm{~b}$ & $90.08 \mathrm{~cd}$ & $94.59 \mathrm{~b}$ & $98.23 \mathrm{~b}$ & $111.81 \mathrm{~b}$ \\
\hline HM31 & $11.54 \mathrm{ab}$ & $21.08 \mathrm{a}$ & $25.60 \mathrm{a}$ & $48.87 \mathrm{a}$ & $58.09 \mathrm{a}$ & $67.76 \mathrm{a}$ & $68.01 \mathrm{a}$ & $89.56 \mathrm{a}$ \\
\hline HM33 & $41.33 \mathrm{de}$ & $50.73 \mathrm{~b}$ & $58.65 \mathrm{~b}$ & $81.33 \mathrm{~b}$ & $91.55 \mathrm{~cd}$ & $98.68 \mathrm{~b}$ & $100.85 \mathrm{~b}$ & $118.49 \mathrm{~b}$ \\
\hline ANOVA & $\mathrm{p}<0.001$ & & & & & & & \\
\hline
\end{tabular}

HM - Heat-modified / toplinski modificirani uzorci. *Means with the same small letter are not significantly different in Duncan's mean separation test. / Srednje vrijednosti označene istim malim slovom nisu signifikantno različite prema Duncanovu testu. 
nificant difference in water absorption compared to the control sample. As water absorption (\%) changed with time, the lowest water absorption in undensified group was obtained in HT23 (122.71 \%) after 360 hours. The lowest water absorption in the densified wood in the interval from 1 hour to 360 hours was determined in HT31 compared to the densified control. The water absorption in the first 24 hours in the densified wood continued to be water intake without heat treatment temperature and duration effective, and after 24 hours HT23, HT31 and HT33 showed lower water absortion than the densified control sample. When compared to the undensified control sample (129.62\%), the lowest water absorption percentage was determined in HM23 (122.71 \%). Likewise, in densified samples, the lowest decrease in HM31 (89.56 \%) was calculated according to control samples (119.02 \%).Also, Cai et al. (2013) noted that the water absorption of densified wood with and without heat treatment was affected by compression temperature, compression ratio and pressure holding time. Similar findings were obtained by Unsal et al. (2009), and they indicated that the compressed pine decreased water absorption for $5 \mathrm{MPa}$ at $120{ }^{\circ} \mathrm{C}$ compared to uncompressed pine, while higher compression temperature and compression ratio increased water absorption.

\section{CONCLUSIONS}

\section{ZAKLJUČAK} below:

The main outputs of this study are summarized

1. Density of undensified poplar wood was minimally (1 \%) affected by heat modification. However, density was influenced by heat modification before densification and it increased density by $34 \%$.

2. Volumetric swelling of undensified poplar wood decreased significantly only at $200{ }^{\circ} \mathrm{C}$ heat modification. Moreover, the densification increased the volumetric swelling due to the springback effect.

3. In comparison to oven dry density $\left(D_{0}\right)$, the oven dry density after soaking $\left(D_{0 \mathrm{~S}}\right)$ decreased in undensified and densified samples at the rate of $1 \%$ and $55 \%$, respectively. In addition, the mass loss increased with the increase of heat modification temperature in all samples, notwithstanding the densification process. Densification process increased the volume weight and fiber saturation point compared to heat modification.

4. No significant correlation was found between water absorption time and heat modification process for undensified samples. On the other hand, in densified samples, water absorption retention improved as the heat modification temperature and duration increased. Besides, the effect of the application time increased depending on temperature increase.

5. Poplar trees are fast growing and have low durability. However, poplar wood has become a material with high density and lower water absorption by heat modification and densification process. Thus, species with low durability can be converted to wood material of high density and extended service life by heat modification and densification process.
6. One of the remarkable characteristics of this study is that no chemicals have been used during the process and there have been no side effects that could adversely affect human and environmental health during and after the process.

7. In order to make the above physical properties meaningful and useful at the desired level, mechanical properties should also be researched in future as a part of this study.

\section{Acknowledgement - Zahvala}

This work was supported by a grant from the Kahramanmaras Sutcu Imam University Scientific Research Projects Unit, Project Number: 2013/2-40M.

\section{REFERENCES}

5. LITERATURA

1. Abraham, J.; Nemeth, R.; Molnar, S., 2010: Thermomechanical densification of Pannonia Poplar. In: Proceedings of the final conference of COST Action E53: 'Quality control for wood \& wood products’ 4-7th May 2010, Edinburgh. 2010.05.04-2010.05.10. pp. 282-292.

2. Bal, B. C.; Bektaş, İ., 2013: The Effects of Heat Treatment on Some Mechanical Properties of Juvenile Wood and Mature Wood of Eucalyptus grandis. Drying Technology, 31: 479-485. http://dx.doi.org/10.1080/07373937.2012.742910.

3. Candan, Z.; Korkut, S.; Unsal, O., 2013: Thermally compressed poplar wood (TCW): Physical and mechanical properties. Drvna industrija, 64 (2): 107-211. http://dx.doi.org/10.5552/drind.2013.1216.

4. Cai, W.; Yang, J.; Liu, Z.; Hu, Y.; Weisberg, P. J., 2013: Post-fire tree recruitment of a boreal larch forest in Northeast China. Forest Ecol Manag. 307: 20-29. http://dx.doi.org/10.1016/j.foreco.2013.06.056.

5. Cao, Y.; Lu, J.; Huang, R.; Jiang, J., 2012: Increased dimensional stability of Chinese fir through steam-heatthreatment. Eur. J. Wood Prod. 70: 441-444. http://dx.doi.org/10.1007/s00107-011-0570-y.

6. Diouf, P. N.; Stevanovich T.; Cloutier, A.; Fang, C. H.; Blanchet, P.; Koubaa, A.; Mariotti, N., 2011: Effects of thermo-hygro-mechanical densification on the surface characteristics of trembling aspen and hybrid poplar wood veneers. Applied Surface Science, 257: 3558-3564. http://dx.doi.org/10.1016/j.apsusc.2010.11.074.

7. Fang, C. H.; Cloutier, A.; Blanchet, P.; Koubaa, A., 2012: Densification of wood veneers combined with oil-heat treatment. Part II: Hygroscopicity and mechanical properties. BioResources, 7 (1): 925-935. http://dx.doi.org/10.15376/biores.7.1.0925-0935.

8. Garcia, R. A.; Carvalho, A. M.; Latorraca, J. V. F.; Matos, J. L. M.; Santos, W. A.; Silva, R. F. M., 2012: Nondestructive evaluation of heat-treated Eucalyptus grandis Hill ex Maiden wood using stress wave method. Wood Sci. Technol., 46: 41-52. http://dx.doi.org/10.1007/s00226-010-0387-6.

9. Gong, M.; Lamason, C., 2007: Improvement of surface properties of low density wood: Mechanical modification with heat treatment. Research report, Project No: UNB57, Value to Wood No: UNB57 Natural Resources Canada.

10. Gong, M.; Lamason, C.; Li, L., 2010: Interactive effect of surface densification and postheat-treatment on aspen wood. J Mater Process Tech., 210: 293-296. http://dx.doi.org/10.1016/j.jmatprotec.2009.09.013. 
11. Kord, B.; Kialashaki, A.; Kord, B., 2010: The within-tree variation in wood density and shrinkage, and their relationship in Populus euramericana. Turk. J. Agric. For., 34: 121-126. http://dx.doi.org/10.3906/tar-0903-14.

12. Kurt, R., 2010: Suitability of three hybrid poplar clones for laminated veneer lumber manufacturing using melamine urea formaldehyde adhesive. BioResources, 5 (3): 1868-1878.

http://dx.doi.org/10.15376/biores.5.3.1868-1878.

13. Metsä-Kortelainen, S.; Viitanen, H., 2011: Wettability of sapwood and heartwood of thermally modifi ed Norway spruce and Scots pine Eur. J. Wood Prod., 70 (1-3): 135139. http://dx.doi.org/10.1007/s00107-011-0523-5.

14. Rautkari, L.; Properzi, M.; Pichelin, F.; Hughes, M., 2008: An innovative thermo densification method for wooden surfaces. In: Proceedings of the 10 th World Conference on Timber Engineering, Miyazaki, Japan, pp.177-184.

15. Rowell, R.; Ibach, E. E.; McSweeny, J.; Nilsson, T., 2009: Understanding decay resistance, dimensional stability and strength changes in heat treated and acetylated wood. Proceedings of 4th European conference on wood modification, Stockholm, 489-502. https://doi.org/10.1080/17480270903261339

16. Schneider, A., 1973: Investigation on the convection drying of lumber at extremely high temperatures. Part II: Drying degrade, changes in sorption, colour and strength of pine sapwood and beech wood at drying temperatures from 110 to $180{ }^{\circ} \mathrm{C}$. Holz. als Roh-und Werkstoff, 31: 198-206. https://doi.org/10.1007/BF02613842

17. Tjeerdsma, B. F.; Boonstra, M.; Militz, H., 1998: Thermal modification of non-durable wood species 2. Improved wood properties of thermal treated wood. In: Proceedings of 29th Annual meeting, Maastricht-The Low Countries, 14-19 May. Doc. No. IRG/WP/98-40124.

18. Tjeerdsma, B. F.; Militz, H., 2005: Chemical changes in hydrothermal treated wood: FTIR analysis of combined hydrothermal and dry heat-treated wood. Holz als Rohund Werkstoff, 63 (2): 102-111.

http://dx.doi.org/10.1007/s00107-004-0532-8.
19. Ünsal, Ö.; Kartal, S. N.; Candan, Z.; Arango, R. A.; Clausen, C. A.; Green, F., 2009: Decay and termite resistance, water absorption and swelling of thermally compressed wood panels. International Biodeterioration, 63: 548-552. http://dx.doi.org/10.1016/j.ibiod.2009.02.001.

20. Wang, J.; Cooper, P., 2005: Effect of oil type, temperature and time on moisture properties of hot oil-treated wood. Holz Roh Werkst, 63: 417-422. http://dx.doi.org/10.1007/s00107-005-0033-4.

21. Wang, J. M.; Zhao, G. J.; Lida, I., 2000: Effect of oxidation on heat fixation compressed wood of China fir. Forestry studies in China, 2: 73-79.

22. Weiland, J. J.; Guyonnet, R., 2003: Study of chemical modifications and fungi degradation of thermally modified wood using DRIFT spectroscopy. Holz als Rohund Werkstoff, 61: 216-220. http://dx.doi.org/10.1007/s00107-003-0364-y.

23. Welzbacher, C. R.; Wehsener, J.; Rapp, A. O.; Haller, P., 2008: Thermo-mechanical densification combined with thermal modification of Norway spruce in industrial scale- dimensional stability and durability aspects. Holz als Roh-und Werkstoff, 66: 39-49.

http://dx.doi.org/10.1007/s00107-007-0198-0.

\section{Corresponding address:}

Prof. Dr. İBRAHIM BEKTAŞ, Ph.D.

Kahramanmaras Sutcu Imam University, Faculty of Forestry

Department of Forest Industry Engineering 46100 Kahramanmaras, TURKEY

e-mail: ibtas@ksu.edu.tr 